\title{
APLIKASI SISTEM INFORMASI GEOGRAFIS (SIG) UNTUK IDENTIFIKASI PERUBAHAN SEMPADAN SUNGAI MUSI \\ DI KOTA PALEMBANG (1922 - 2012)
}

\author{
M. Asyroful Mujib, Murjainah, Ratna Wulandari Daulay \\ Program Studi Pendidikan Geografi, Universitas PGRI Palembang \\ m.asyroful.mujib@gmail.com ; murjainah@gmail.com ; ratnadaulay@gmail.com
}

\begin{abstract}
ABSTRAK
Sungai senantiasa mengalami perubahan dari segi ruang dan waktu, khususnya Sungai Musi di Kota Palembang yang memiliki peran strategis sebagai urban rivers mulai dari pemerintahan kolonial hingga saat ini. Salah satunya adalah perubahan sempadan sungai akibat erosi dan sedimentasi. Tujuan dari penelitian ini adalah untuk mengidentifikasi seberapa besar perubahan sempadan Sungai Musi dalam kurun waktu 90 tahun terakhir dan pemanfaatan lahan hasil sedimentasi sungai saat ini. Fokus penelitian ini adalah Sempadan Sungai Musi sepanjang 10,85 km dari panjang total 27,47 km Sungai Musi yang membelah Kota Palembang.

Metode penelitian yang diterapkan adalah deskriptif kualitatif dengan penerapan teknologi Sistem Informasi Geografis (SIG). Data yang diolah berupa Peta Sejarah Kota Palembang Tahun 1922 dan Citra satelit Quickbird Tahun 2012 yang dianalisis dengan teknik overlay berupa symmetrical difference dan geoprocessing. Hasil dari penelitian ini menunjukkan bahwa tingkat sedimentasi di sempadan Sungai Musi sangat besar dibandingkan tingkat erosinya yaitu sebesar 93\%. Kecamatan Gandus dan Kecamatan Seberang Ulu I memiliki wilayah tersedimentasi yang paling besar yaitu 31\% dan $29 \%$ yang banyak dipengaruhi oleh aktifitas manusia. Sebaliknya, wilayah yang tererosi cukup besar adalah Kecamatan Kertapati sebesar 65\% akibat pengaruh arus dari Sungai Kramasan. Hasil sedimentasi di sempadan Sungai Musi banyak dimanfaatkan menjadi lahan permukiman $(47,4 \%)$, waduk/danau $(22,3 \%)$, rawa $(10,7 \%)$ dan 7 penggunaan lahan yang lain dengan kisaran $0,2-6,6 \%$. Hasil akhir penelitian ini berupa peta perubahan sempadan sungai musi di kota Palembang. Hasil temuan penelitian ini, dapat dijadikan acuan penelitian selanjutnya dalam mengembangkan produk pembelajaran sebagai upaya mengenalkan perubahan Sungai Musi di Kota Palembang baik di sekolah maupun pada mata kuliah Sistem Informasi Geografis, Geologi, Geomorfologi, dan Hidrologi.
\end{abstract}

Kata Kunci : Sistem Informasi Geografis (SIG), Sungai Musi, sempadan sungai 


\section{PENDAHULUAN}

Sungai merupakan saluran terbuka yang terbentuk secara alamiah di atas permukaan bumi, tidak hanya menampung air tetapi juga mengalirkannya dari bagian hulu ke bagian hilir (Junaidi, 2014). Sungai merupakan salah satu ekosistem, yaitu salah satu lahan dengan sistem ekologi yang terdiri atas komponen-komponen yang saling berintegrasi sehingga membentuk suatu kesatuan (Asdak, 1995). Apabila salah satu komponen terganggu, maka hal ini akan mempengaruhi komponen lain yang ada pada sungai tersebut.

Sungai senantiasa mengalami dinamika baik secara alami maupun akibat aktifitas manusia. Secara alami perubahan morfologi sungai banyak dipengaruhi oleh proses erosi dan sedimentasi yang tergantung pada kondisi Daerah Aliran Sungai (DAS), sedangkan aktifitas manusia yang berpengaruh terhadap dinamika sungai diantaranya adalah reklamasi, penimbunan sedimen, alih fungsi sempadan, dan pemotongan jalur sungai (Brookes, 1994; Li, et al. 2007). Periode meningkatnya aktifitas manusia dalam mempengaruhi dinamika sungai telah terjadi dalam kurun waktu 100-500 tahun terakhir (Gregory, 1977; Petts, 1989; Ollero, 2010). Aktifitas manusia diyakini membawa dampak yang cukup signifikan pada dinamika sungai dibandingkan bencana alam ekstrim seperti banjir, longsor, dan kekeringan (Petts and Amoros, 1984; Li, et al. 2007). Penelitian ini akan memfokuskan pada perubahan geometri khususnya pada perubahan sempadan sungai dengan melihat perubahan secara temporal dalam kurun waktu 90 tahun terakhir.

Perubahan sempadan sungai adalah perubahan fungsi sebagian atau seluruh kawasan lahan sungai dari fungsinya yang semula (seperti yang direncanakan) menjadi fungsi lain yang menjadi dampak negatif (masalah) terhadap lingkungan dan maupun dampak positif (manfaat) melalui potensi lahan itu sendiri (Utomo, et al., 1992). Perubahan sempadan sungai merupakan salah satu permasalahan tentang penggunaan lahan saat ini. Adanya dinamika sungai pada proses sedimentasi dan erosi sungai merupakan faktor utama yang berpengaruh dalam perubahan garis sungai (Bagli and Soille, 2003; Sunarto 2004; Mills, et al. 2005). Proses sedimentasi terutama disebabkan oleh pengangkutan material dari daratan pada aliran sungai yang kemudian diendapkan pada muara-muara sungai sehingga membentuk delta. Selain itu, faktor utama lainnya penyebab perubahan sempadan sungai karena adanya pertumbuhan pembangunan yang cepat akibat banyaknya permintaan 
masyarakat pada beberapa kasus yang kurang terkendali, tidak sesuai dengan rencana tata ruang, tidak serasi dengan lingkungan, dan tidak selaras dengan konsep pembangunan berkelanjutan.

Berkembangnya sempadan sungai sebagai kawasan budidaya membawa dampak menurunnya fungsi sempadan sungai yang berakibat pada pengurangan kapasitas resapan air hujan sehingga berdampak dengan meningkatnya luapan air hujan dari penampungannya. Menurut Peraturan Pemerintah RI No. 38 Tahun 2011 tentang Sungai, idealnya sempadan sungai berjarak 30 meter antara kirikanan tepi sungai bagi kawasan sungai kota yang tak bertanggul, dan 3 meter antara kiri-kanan tepi sungai bagi kawasan sungai kota yang bertanggul.

Sempadan Sungai Musi di Kota Palembang merupakan salah satu objek yang diteliti untuk mengidentifikasi perubahan sempadan sungai dalam kurun waktu 90 tahun terakhir yaitu dari tahun 1922 hingga 2012. Pemanfaatan informasi historis dalam bentuk peta, foto udara, citra satelit, dan survey dapat memberikan informasi kondisi masa lalu untuk penelitian geografi khususnya di bidang geomorfologi (Trimble and Cooke, 1991). Penelitian perubahan garis sungai juga telah banyak dilakukan (seperti Gurnell, et al., 1994; Gurnell, 1997; Li, et al. 2007; Ollero, 2010; Brookes, 1994 dan Sarma, et al. 2007). Tingkat kedetailan untuk analisis perubahan morfologi sungai ini tergantung dari skala peta dan jumlah peta historis yang tersedia (Gurnell, 1997). Palembang semenjak ditetapkan sebagai kota (Gemeente) oleh pemerintah kolonial Belanda pada Tahun 1906, pemetaan wilayah untuk masterplan kota telah dilakukan secara bertahap dengan skala besar (Santun, 2011). Oleh karena itu, dengan adanya Peta Kota Palembang (Palembang City Map) Tahun 1922 skala 1:5.000 dapat menjadi dasar untuk melihat perubahan sempadan sungai dengan kondisi eksisting (saat ini) yang didukung dengan Citra satelit Quickbird Tahun 2012 yang memiliki resolusi spasial 0,6-2,4 meter dari BAPPEDA.

Pemanfaatan Sistem Informasi Geografis (SIG) dalam analisis dinamika sempadan sungai untuk skala waktu yang berbeda dapat dilakukan secara cepat, akurat, memiliki sejumlah kelebihan dibandingkan prosedur manual, serta mampu merepresentasikan beberapa tipe fenomena secara keruangan (Gurnell, et al., 1994; Goodchild, 2009). Hasil olahan data SIG ini juga dapat digunakan untuk analisis area terdampak akibat perubahan sungai, serta prediksi dampak yang ditimbulkan pada masa mendatang. 
Oleh karena itu, dinamika sungai di Kota Palembang yang menjadi daerah penelitian divisualisasikan secara spasial dan diketahui orientasi perubahannya. Tujuan dari penelitian ini adalah (1) mengidentifikasi seberapa besar perubahan sempadan Sungai Musi di Kota Palembang dalam kurun waktu 90 tahun terakhir dengan menggunakan aplikasi SIG, dan (2) mengetahui pemanfatan lahan hasil sedimentasi sungai saat ini;

\section{DESKRIPSI DAERAH PENELITIAN}

Sungai Musi yang membelah Kota Palembang memiliki panjang sungai 27,47 Km. Dari total panjang sungai tersebut, penelitian ini memfokuskan pada Sungai Musi yang berada di pusat Kota Palembang dengan panjang sungai 10,85 Km mulai dari koordinat UTM 48S 477935,691 mT dan 9669985,21 mU hingga koordinat 469554,997 mT dan 966016,628 mU. Sungai Musi yang menjadi fokus penelitian masuk dalam wilayah Sub DAS Musi Hilir dengan panjang 6,09 Km dan Sub DAS Batang Peledas dengan panjang 4,8 Km. Secara administrasi, sempadan sungai dalam penelitian ini masuk dalam wilayah Kecamatan Kertapati, Seberang Ulu I, Seberang Ulu II untuk di sebelah selatan Sungai Musi, dan di sebelah utara sungai mencakup wilayah Kecamatan Ilir Barat II, Bukit Kecil, llir Timur I, dan Ilir Timur II (Gambar 1).

Secara geologi, sempadan sungai di daerah penelitian dominan tertutup oleh endapan rawa dan alluvium yang merupakan sedimen pada Masa Kuarter. Kedua endapan ini di daerah Ilir menutupi Formasi Muaraenim bagian bawah yang berumur Miosen. Badri (1983) mendeskripsikan bahwa Formasi Muaraenim bagian bawah memiliki sebaran yang cukup luas dan umumnya telah mengalami perlipatan, terdiri atas batu lempung dan batu lanau tufan dengan sisipan batubara. Endapan alluvium yang dominan terdapat di Sempadan Sungai Musi Kecamatan Seberang Ulu I dan Seberang Ulu II menurut Moechtar (2007) memiliki lithologi batuan yang terdiri atas pasir kasar, pasir halus, lanau, lempung, lempung lanauan, lempung tufan, lanau berhumus bersifat lempungan sampai ke lempung bergambut, sedangkan endapan rawa memiliki lithologi batuan yang terdiri atas lanau organik bersifat lempungan, lempung organik dengan sedikit kandungan pasir yang berwarna gelap.

Iklim di wilayah DAS Musi tergolong iklim basah. Berdasarkan klasifikasi Schmidt dan Ferguson tipe iklim di Wilayah DAS Musi sebagian besar adalah tipe A (sangat basah). Suhu udara rata-rata berkisar antara $26-28,7^{\circ} \mathrm{C}$ Musim hujan terjadi antara bulan November hingga April dengan curah hujan rata-rata 
sebesar 202,7 mm dan jumlah hari hujan terbanyak pada bulan Desember dengan kelembaban relatif rata-rata adalah 83,0\% (BP DAS Musi dan Forum DAS Sumsel, 2011; BPS Kota Palembang, 2015). Kondisi iklim yang sangat basah berperan besar dalam menunjang proses erosi dan sedimentasi di DAS. Hasil analisa dari BP DAS Musi dan Forum DAS Sumsel (2011) menyebutkan bahwa tingkat erosi di DAS Musi Hilir dan DAS Batang Peledas berada pada kategori erosi kelas I ( $<15 \mathrm{Ton} / \mathrm{Ha} / \mathrm{Th})$ dengan luas masing-masing sebesar 224.638,62 $\mathrm{Ha}$ dan 84.456,05 $\mathrm{Ha}$. Luasan wilayah ini mencakup penyebaran lahan kritis di dua DAS tersebut mulai dari tingkat tidak kritis hingga sangat kritis.

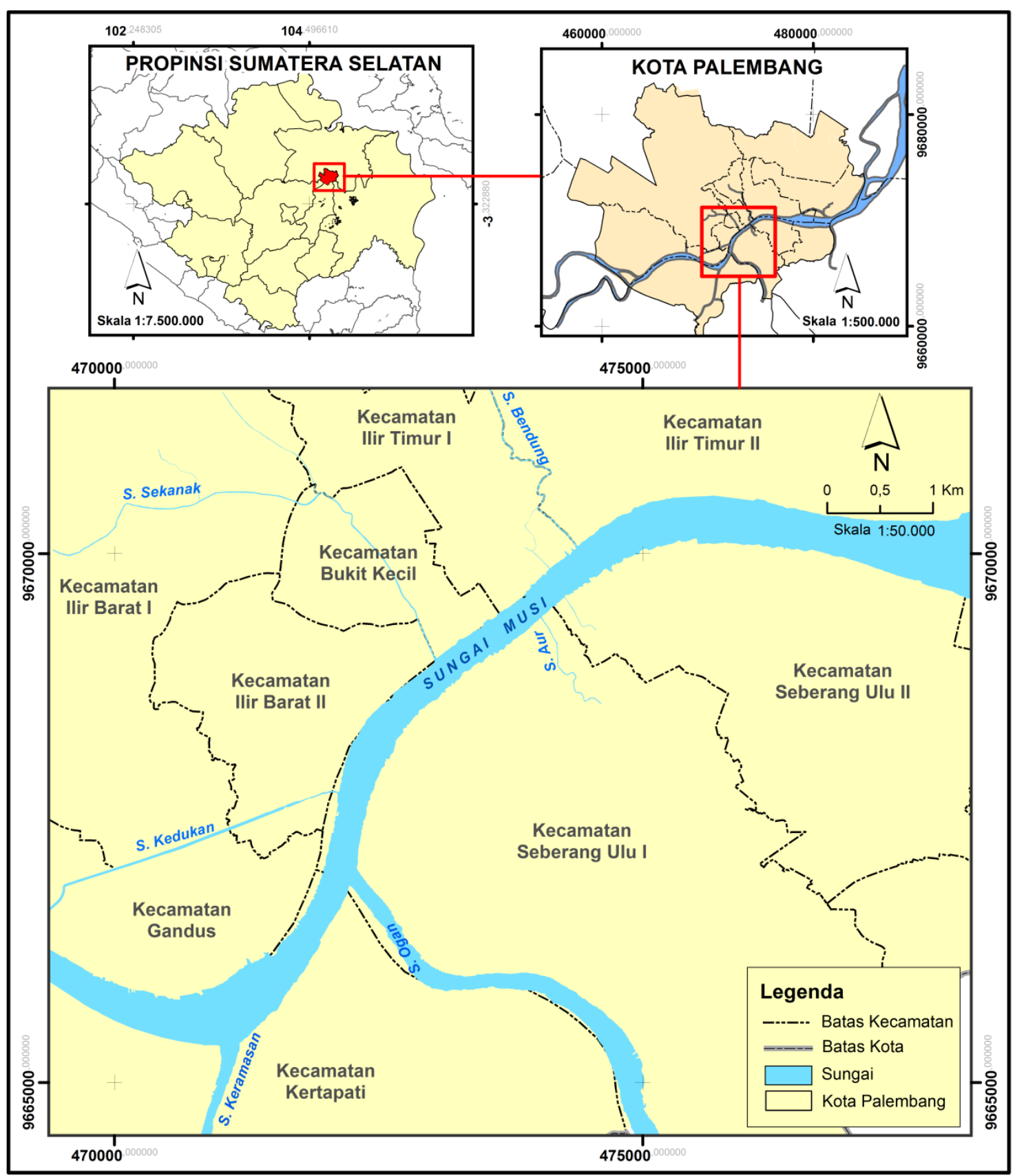

Gambar 1. Daerah penelitian 


\section{METODE PENELITIAN}

Perubahan sempadan Sungai Musi di Kota Palembang dianalisis berdasarkan data dari dua waktu yang berbeda, yaitu (1) Peta Kota Palembang (Palembang City Map) skala 1:5.000 Tahun 1922 dari Kaartenzaal Centrale Bibliothee Kon. Inst. V.d. Tropen Amsterdam, Belanda yang diarsipkan oleh Leiden University; dan (2) Citra satelit Quickbird untuk Rencana Tata Ruang Kota Palembang Tahun 2012 yang berasal dari BAPPEDA Kota Palembang. Perubahan sempadan sungai dianalisis melalui perbandingan perubahan lebar sungai dan sedimen bar. Peta tahun 1922 digeoreferensikan menggunakan GIS untuk meningkatkan akurasi perubahan sempadan sungai. Informasi dari citra satelit Quickbird Tahun 2012 diekstraksi dan keduanya didigitasi sesuai dengan batas sempadan sungai serta penggunaan lahan pada tahun 2012.

Metode yang digunakan untuk analisis perubahan garis sungai dalam kurun waktu 90 tahun terakhir adalah metode Overlay sebagai salah satu metode analisis spasial dalam SIG. Istilah Overlay diilhami dari proses menempatkan peta transparan diatas peta lain yang memiliki fenomena berbeda untuk menghasilkan peta baru. Kombinasi dari dua peta atau lebih yang memiliki geometri dan attribut berbeda akan menghasilkan peta baru sesuai dengan tujuan si pembuat (Chang, 2012; Kennedy, 2013). Lebih lanjut, Chang (2012) menjelaskan bahwa teknik Overlay yang umum digunakan adalah (1) Union, untuk menggabungkan seluruh fitur dari peta-peta input; (2) Intersect yaitu teknik yang hanya menggabungkan fitur yang sama dari dua input; (3) Symmetrical Difference yaitu teknik yang mengambil fitur di luar area yang sama dari peta input; dan (4) Identity, untuk menghasilkan peta output yang hampir sama dengan peta input namun memiliki tambahan atribut dan geometri dari peta identitas.

Teknik Overlay yang digunakan untuk melihat perubahan garis sungai dari Tahun 1922 hingga Tahun 2012 adalah teknik symmetrical difference dengan menempatkan fitur Sungai Musi Tahun 2012 di atas fitur Sungai Musi Tahun 1922. Teknik Symmetrical Difference mampu membedakan fitur di luar area yang sama, sehingga dapat diketahui perubahan akibat proses sedimentasi dan erosi yang terjadi dalam kurun waktu 90 tahun terakhir dan proses perubahan lahan sempadan sungai akibat aktifitas manusia (Gambar 3). Konsep dasar teknik symmetrical difference dianalogikan pada Gambar 2a. Tahap selanjutnya adalah dengan melihat sebaran perubahan garis sungai di setiap wilayah kecamatan. 
Teknik yang digunakan adalah Geoprocessing dengan teknik intersect yaitu memotong wilayah yang sama dari fitur area kecamatan dan sempadan sungai Tahun 1922-2012, konsep dasar teknik intersect dianalogikan pada Gambar 2b.

a

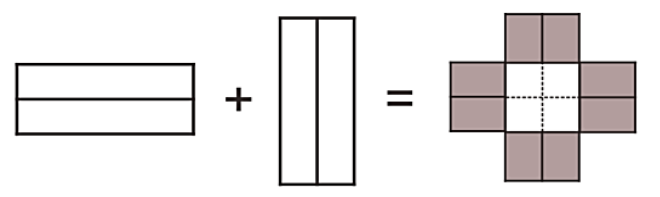

b

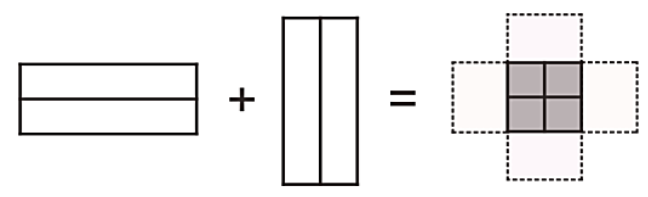

Gambar 2. (a) Teknik Symmetrical Difference yang menghasilkan fitur di luar area yang sama dari peta input; (b) Teknik intersect yang hanya menggabungkan fitur yang sama dari dua peta input (Chang, 2012: 227)

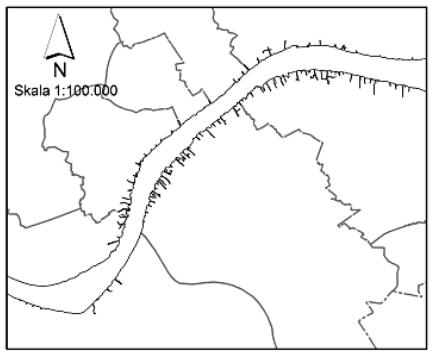

Sungai Musi 1922

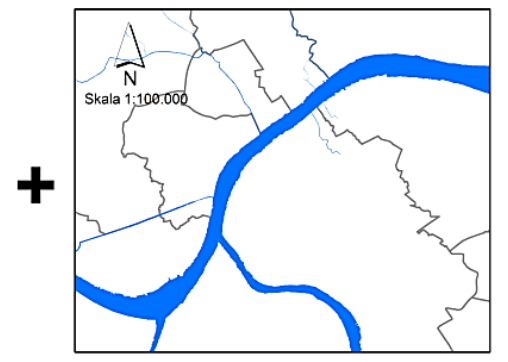

Sungai Musi 2012

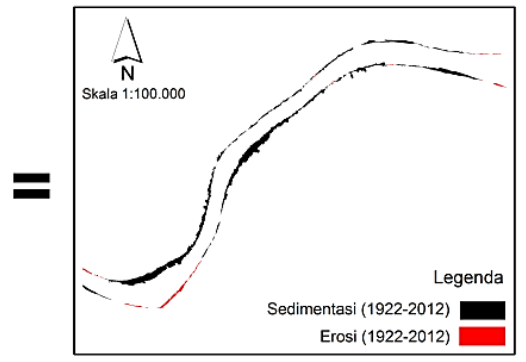

Hasil Overlay

Teknik Symmetrical Difference

Gambar 3. Hasil overlay peta Sungai Musi 1922 dan Sungai Musi 2012 menggunakan teknik Symmetrical Difference

\section{HASIL PENELITIAN DAN PEMBAHASAN}

\section{Pemanfaatan Data Penginderaan Jauh dan Sistem Informasi Geografis (SIG) untuk Identifikasi Perubahan Sempadan Sungai Musi}

Data penginderaan jauh (PJ) pada penelitian ini berupa data satelit Quickbird tahun 2012. Citra Quickbird memiliki kelebihan resolusi spasialnya yang halus $(0,8 \mathrm{~m})$ sehingga objek berukuran kecil dapat direkam, kenampakan objek seperti wujud sebenarnya di lapangan, serta data yang direkam dalam bentuk digital sehingga memudahkan pengolahannya. Aplikasi Sistem Informasi Geografis (SIG) merupakan cara untuk mengolah data spasial PJ. Hasil overlay (tumpangsusun) menunjukkan bahwa tingginya proses erosi dan sedimentasi di daerah aliran sungai secara lambat laun akan berakumulasi membentuk morfologi sungai, hal ini dapat dianalisa dengan memanfaatkan Sistem Informasi Geografis. 
Hasil perubahan sempadan Sungai Musi dalam kurun waktu 90 tahun terakhir (Tahun 1922-2012) di daerah penelitian ditunjukkan dari perbedaan lebar sungai yang menghasilkan penambahan sempadan sungai akibat proses sedimentasi secara alami dan sedimentasi oleh aktifitas manusia. Di sisi lain, proses pengurangan luasan sempadan sungai karena proses erosi juga akan mengiringi perubahan morfologi sungai. Hasil analisa dari peta Kota Palembang tahun 1922 dan Citra satelit Quickbird tahun 2012 menunjukkan bahwa sempadan Sungai Musi yang mengalami proses erosi dan sedimentasi di daerah penelitian memiliki luas total $721.503 \mathrm{~m}^{2}$. Dari luas total tersebut, wilayah sempadan sungai hasil sedimentasi sebesar 93\% (668.945 $\left.\mathrm{m}^{2}\right)$ dengan perubahan yang sangat signifikan dibandingkan dengan sempadan sungai yang tererosi yaitu hanya sebesar $3 \%\left(52.558 \mathrm{~m}^{2}\right)$.

Proses sedimentasi terjadi di sepanjang sempadan sungai yang terdapat di 8 kecamatan. Selama kurun waktu 90 tahun terakhir, sedimentasi tertinggi terjadi di Kecamatan Gandus sebesar 31,14\% (208.305 $\mathrm{m}^{2}$ ). Sempadan sungai di Kecamatan Gandus berada pada sisi dalam sungai meander (inside of banks) dengan arus sungai yang lebih lambat, sehingga pada wilayah sempadan sungainya akan banyak terjadi akumulasi endapan sedimen. Hal ini berbeda jika melihat kondisi sempadan sungai di Kecamatan Kertapati yang berada pada sisi luar sungai meander (outer of banks) dengan kondisi arus sungai yang lebih deras dibandingkan arus di sisi dalam sehingga sempadan sungai di kecamatan ini lebih banyak yang tererosi. Selain itu, adanya aliran sungai yang masuk dari Sungai Kramasan membuat sempadan yang berada tepat di sisi pertemuan kedua sungai ini mengalami erosi yang cukup besar. Luas sempadan sungai yang tererosi di Kecamatan Kertapati seluas 34.585\% (65,80\%) dan merupakan wilayah yang mengalami erosi paling tinggi dibandingkan kecamatan yang lain dalam kurun waktu 90 tahun terakhir. Sempadan sungai di Kecamatan Gandus dan Kecamatan Kertapati merupakan wilayah yang mengalami erosi dan sedimentasi paling tinggi dibandingkan dengan kecamatan yang lain. Luasan wilayah yang tererosi dan hasil sedimentasi di tiap kecamatan dijabarkan pada Tabel 1 dan Gambar 4. 
.Tabel 1. Luas wilayah hasil sedimentasi dan erosi dari tahun 1922-2012 berdasarkan wilayah administrasi di daerah penelitian

\begin{tabular}{llrrrrrr}
\hline \multirow{2}{*}{ NO } & \multirow{2}{*}{ KECAMATAN } & \multicolumn{2}{c}{ Sedimentasi (1922-2012) } & Erosi (1922-2012) & \multicolumn{2}{c}{$\begin{array}{c}\text { Rata-Rata Lebar } \\
\text { Sedimentasi \& Erosi }\end{array}$} \\
\cline { 3 - 8 } & & Luas $\left(\boldsymbol{m}^{2}\right)$ & $\%$ & Luas $\left(\boldsymbol{m}^{2}\right)$ & $\%$ & Sedimentasi $(\boldsymbol{m})$ & Erosi $(\boldsymbol{m})$ \\
\hline $\mathbf{1}$ & GANDUS & $\mathbf{2 0 8 . 3 0 5}$ & $\mathbf{3 1 , 1 4}$ & 5.893 & 11,21 & $\mathbf{1 1 7 , 3 3}$ & 19 \\
$\mathbf{2}$ & KERTAPATI & 21.271 & 3,18 & $\mathbf{3 4 . 5 8 5}$ & $\mathbf{6 5 , 8 0}$ & 22 & $\mathbf{3 0 , 2 7}$ \\
$\mathbf{3}$ & SEBERANG ULU I & 200.094 & 29,91 & - & - & 79,06 & - \\
$\mathbf{4}$ & SEBERANG ULU II & 103.406 & 15,46 & 7.224 & 13,74 & 38,53 & 26,3 \\
$\mathbf{5}$ & ILIR BARAT II & 48.041 & 7,18 & - & - & 41,42 & 21,43 \\
$\mathbf{6}$ & BUKIT KECIL & 13.909 & 2,08 & - & - & 21,43 & - \\
$\mathbf{7}$ & ILIR TIMUR I & 14.401 & 2,15 & 856 & 1,63 & 22,86 & 11,5 \\
$\mathbf{8}$ & ILIR TIMUR II & 59.518 & 8,90 & 4.001 & 7,61 & 22,5 & 10 \\
\hline & & $\mathbf{6 6 8 . 9 4 5}$ & $\mathbf{1 0 0}$ & $\mathbf{5 2 . 5 5 8}$ & $\mathbf{1 0 0}$ & &
\end{tabular}

Sumber : Analisis data sekunder (Peta Kota Palembang tahun 1922 dan Citra satelit Quickbird tahun 2012)

Sempadan sungai yang juga banyak mengalami sedimentasi adalah di Kecamatan Seberang Ulu I dengan luasan 200.094 m² $^{2}(29,91 \%)$. Kecamatan Seberang Ulu I berada di sisi dalam sungai meander dengan tingkat sedimentasi yang lebih besar dibanding tingkat erosinya, bahkan wilayah yang tererosi tidak ada (Gambar 4). Hal ini dapat dipahami karena Kecamatan Seberang Ulu I merupakan wilayah penghubung antara daerah Ulu dengan daerah llir bahkan sebelum dibangunnya jembatan Ampera pada Tahun 1961, kedua daerah ini dihubungkan dengan jasa veerpont (kapal penyeberangan) dari dermaga penyeberangan 16 ilir ke dermaga 10 ulu atau sebaliknya, sehingga aktifitas masyarakat banyak yang terpusat di wilayah ini. Selain itu, pemerintah kolonial belanda (gementee) juga telah menjadikan daerah Seberang Ulu sebagai zona industri yang terletak di kawasan Plaju dan Sungai Gerong, akibatnya terdapat penambahan sempadan sungai Musi oleh campur tangan manusia yang dimanfaatkan untuk aktifitas sosial ekonomi masyarakat.

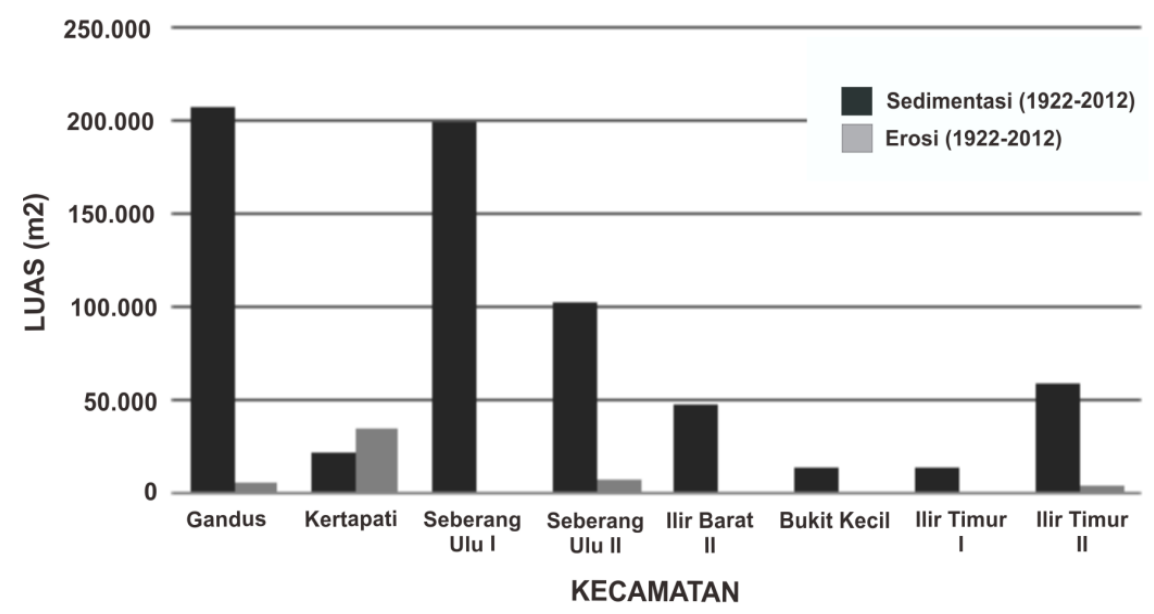

Gambar 4. Perbandingan tingkat erosi dan sedimentasi di 8 kecamatan di Kota Palembang 
Kecamatan llir Barat II dan Kecamatan Bukit Kecil yang berada di seberang Kecamatan Ulu I hanya mengalami penambahan sedimentasi sekitar $7,18 \%$ dan 2,08\%. Kecamatan Ilir Timur I dan Ilir Timur II juga mengalami penambahan sedimen tidak lebih dari $10 \%$. Wilayah sempadan yang tererosi di Kecamatan Ilir Timur II hanya seluas 7,61\% (Tabel 1 dan Gambar 4). Empat kecamatan di daerah Ilir ini menurut Santun (2011) semenjak awal pemerintahan Gementee yaitu sekitar tahun 1925-an telah dijadikan sebagai zona perniagaan yang memanjang pada bagian seberang llir Sungai Musi mulai dari Sungai Rendang hingga Sungai Sekanak. Sepanjang wilayah ini dibangun Pasar 16 llir sebagai pasar induk, gudang penyimpanan barang, kantor perwakilan dagang, dan pabrik industri. Dampak dari pembangunan wilayah yang permanen ini adalah sedikitnya alih fungsi lahan untuk permukiman yang berperan besar dalam penambahan sedimentasi buatan, disamping sedimentasi alami yang pengaruhnya sangat kecil.

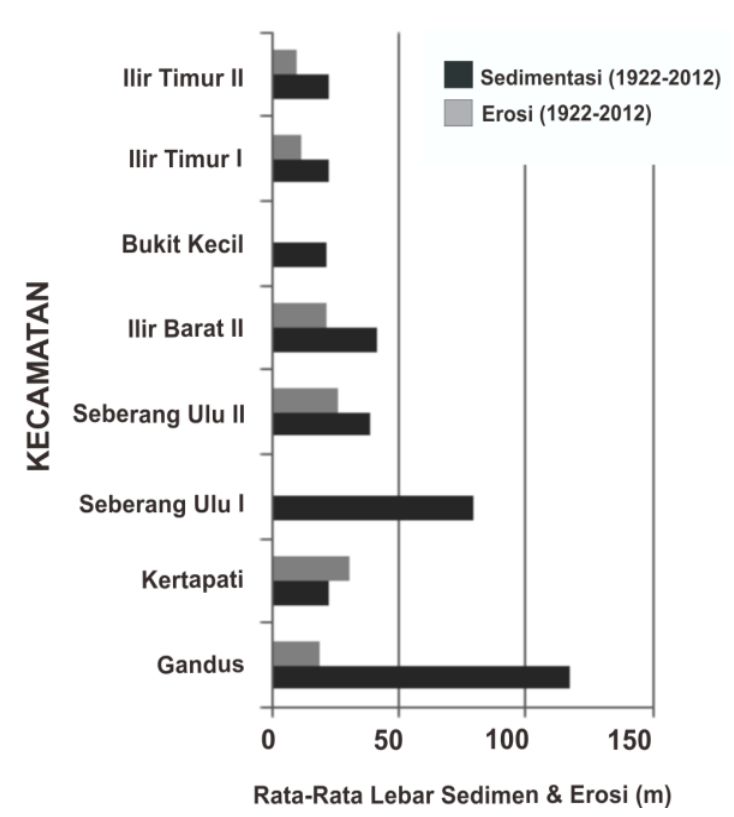

Gambar 5. Rata-rata lebar sedimen dan erosi di 8 kecamatan
Lebar sempadan sungai hasil sedimentasi dalam kurun waktu 90 tahun terakhir ini rata-rata antara 21 hingga 117 meter ke arah darat. Kecamatan Gandus yang merupakan wilayah tersedimentasi paling tinggi memiliki lebar sempadan sungai hingga 117,33 meter ke arah darat hasil dari sedimentasi tersebut. Selanjutnya diikuti oleh Kecamatan Seberang Ulu I dengan rata-rata lebar 79,06 meter ke arah darat yang saat ini telah banyak dialihfungsikan untuk permukiman dan perdagangan (Tabel 1 dan Gambar 5). Sebaliknya untuk wilayah yang tererosi rata-rata lebarnya antara 10 hingga 30 meter ke arah darat. Sempadan Sungai Musi di Kecamatan Kertapati yang tererosi rata-rata memiliki lebar 30 meter, erosi yang paling besar terdapat di pertemuan antara Sungai Musi dan Sungai Kramasan. Akibat pertemuan dua arus yang cukup besar menyebabkan sempadan sungai di bagian seberang ilir mengalami erosi memanjang ke arah hilir. Begitu pula dengan sempadan sungai di Kecamatan Seberang Ulu II dengan rata-rata lebar wilayah tererosi seluas 26,3 meter. Wilayah yang tererosi 
dominan berada pada sisi luar meander (outer of banks) ditunjang dengan pengaruh aktifitas manusia dalam mengurangi wilayah sempadan untuk pemanfaatan sosial ekonomi.

Tingginya tingkat sedimentasi dibandingkan proses erosi dikarenakan Sungai Musi membawa sedimen terlarut yang cukup besar pada musim penghujan. Hal ini ditunjukkan dari survei pembebanan sedimen antara tahun 1986-1987 oleh Kementerian Pekerjaan Umum (1988 dalam Susanto, 2013) yang memperkirakan bahwa beban sedimen di Sungai Musi rata-rata 3,18 ton $/$ hari $/ \mathrm{km}^{2}$. Laju sedimen ini semakin meningkat pada tahun 1999 yang diperkirakan sebesar 2-4 cm/hari berdasarkan hasil pengamatan dari Pimbagro Faskapel South Sumatra dan Third Pelindo Company (1999 dalam Susanto, 2013). Sedimen selama arus rendah mengendap di sepanjang hilir Sungai Musi, terutama dari Tebing Abang menuju laut, karena arus rendah di bagian ini melambat dan akhirnya menjadi seperti air mati (pasang-surut).

\section{Pemanfaatan Lahan Sedimentasi Saat ini}

Lahan hasil sedimentasi di sempadan Sungai Musi dalam kurun waktu 90 tahun terakhir ini telah dimanfaatkan menjadi beberapa tipe penggunaan lahan mulai dari permukiman, jalan, sarana komersial, sarana industri atau perdagangan, sarana ibadah, sawah, kebun, ruang terbuka atau tanah kosong, rawa hingga menjadi danau atau waduk. Lahan tersedimentasi yang memiliki total luas wilayah $669.269 \mathrm{~m}^{2}$ di 8 kecamatan paling banyak dimanfaatkan menjadi lahan permukiman seluas $317.177 \mathrm{~m}^{2}(47,4 \%)$, sedangkan sebagian lainnya ada yang dimanfaatkan sebagai waduk atau danau seluas 149.337 $(22,3 \%)$, menjadi rawa lebak sebesar $10,7 \%$ dan penggunaan lahan lain dengan kisaran di bawah 4\%. Pada wilayah tertentu sarana industri atau pergudangan dan sarana komersial lebih mendominasi penggunaan lahan dengan kisaran 6,3$6,6 \%$. Jenis-jenis penggunaan lahan dominan di wilayah sempadan sungai hasil sedimentasi dijabarkan pada Tabel 2.

Tabel 2. Jenis-jenis penggunaan lahan di sempadan sungai hasil sedimentasi tahun 1922-2012

\begin{tabular}{clrr}
\hline No & \multicolumn{1}{c}{ Penggunaan Lahan } & Luas $\left(\mathbf{m}^{2}\right)$ & \multicolumn{1}{c}{$\%$} \\
\hline 1 & Permukiman & 317.177 & 47,4 \\
2 & Jalan & 2.557 & 0,4 \\
3 & Sarana Komersial & 44.022 & 6,6 \\
4 & Sarana Industri/Pergudangan & 41.992 & 6,3 \\
\hline
\end{tabular}




\begin{tabular}{clrr}
\hline No & \multicolumn{1}{c}{ Penggunaan Lahan } & Luas $\left(\mathbf{m}^{2}\right)$ & \multicolumn{1}{c}{$\%$} \\
\hline 5 & Sarana Ibadah & 1.166 & 0,2 \\
6 & Sawah & 22.966 & 3,4 \\
7 & Kebun & 1.795 & 0,3 \\
8 & Rawa & 71.283 & 10,7 \\
9 & Ruang Terbuka/Tanah Kosong & 16.974 & 2,5 \\
10 & Tubuh Air/Waduk/Danau & 149.337 & 22,3 \\
\hline \multicolumn{2}{l}{ Luas Total } & $\mathbf{6 6 9 . 2 6 9}$ & $\mathbf{1 0 0}$ \\
\hline Sumber : Analisis data sekunder (2016) & &
\end{tabular}

Setiap jenis penggunaan lahan yang dijabarkan pada Tabel 2 memiliki luasan berbeda di setiap kecamatan. Lahan tersedimentasi yang dimanfaatkan sebagai permukiman paling banyak terdapat di Kecamatan Seberang Ulu I dengan luas $160.666 \mathrm{~m}^{2}$ atau $51 \%$ dari luas total lahan sedimentasi yang menjadi permukiman (Tabel 3). Penggunaan lahan untuk permukiman di Kecamatan Seberang Ulu I ditampilkan pada Gambar 6B. Kepadatan penduduk di kelurahan-kelurahan sepanjang sempadan sungai Kecamatan Seberang Ulu I masuk kategori padat dengan kisaran penduduk 20.000 hingga 27.000 orang $/ \mathrm{km}^{2}$ dengan tingkat sanitasi rata-rata kumuh dan sangat kumuh, seperti di Kelurahan 2 Ulu, 3/4 Ulu, 5 Ulu, 7 Ulu, dan Kelurahan 9 Ulu (BPS, 2015). Lahan sedimentasi yang dimanfaatkan sebagai permukiman selanjutnya adalah di Kecamatan Seberang Ulu II sebesar 21\% (68.049 $\left.\mathrm{m}^{2}\right)$ dengan kepadatan penduduk sedang hingga padat. Hampir seluruh lahan sedimen di tiap kecamatan dimanfaatkan menjadi lahan permukiman, kecuali di Kecamatan Bukit Kecil yang sebagian besar lahannya dimanfaatkan sebagai ruang terbuka dan sarana komersial. Luasan masing-masing kategori penggunaan lahan ditampilkan pada Tabel 3.

Kecamatan Gandus yang memiliki lahan sedimentasi paling luas, pada wilayah ini banyak dimanfaatkan sebagai sarana industri/pergudangan seluas $40.949 \mathrm{~m}^{2}$. Pabrik karet, gudang hasil penambangan pasir dan industri perkebunan berada di beberapa zona sempadan sungai di Kecamatan Gandus. Sepanjang sempadan sungai di Kecamatan Gandus masih banyak ditemukan rawa $\left(71.283 \mathrm{~m}^{2}\right)$; sawah $\left(12.961 \mathrm{~m}^{2}\right)$ dan tubuh air $\left(38.548 \mathrm{~m}^{2}\right)$ yang dijabarkan pada Tabel 3. Keempat jenis penggunaan lahan tersebut memiliki luasan paling besar dibandingkan di kecamatan lain. Penggunaan lahan hasil sedimentasi di Kecamatan Gandus ditampilkan pada Gambar 6A. Lahan hasil sedimentasi dan erosi di Sempadan Sungai Kota Palembang ditampilkan pada Gambar 6. 
Tabel 3. Penggunaan lahan hasil sedimentasi di setiap kecamatan Tahun 2012

\begin{tabular}{|c|c|c|c|c|c|c|c|c|c|c|}
\hline \multirow[b]{2}{*}{ NO } & \multirow[b]{2}{*}{ PENGGUNAAN LAHAN } & \multicolumn{8}{|c|}{ KECAMATAN } & \multirow[b]{2}{*}{ Jumlah } \\
\hline & & GANDUS & KERTAPATI & $\begin{array}{c}\text { SEBERANG } \\
\text { ULU I }\end{array}$ & $\begin{array}{l}\text { SEBERANG } \\
\text { ULU II }\end{array}$ & $\begin{array}{c}\text { ILIR } \\
\text { BARAT II }\end{array}$ & $\begin{array}{l}\text { BUKIT } \\
\text { KECIL }\end{array}$ & $\begin{array}{c}\text { ILIR } \\
\text { TIMUR I }\end{array}$ & $\begin{array}{c}\text { ILIR } \\
\text { TIMUR II }\end{array}$ & \\
\hline 1 & Permukiman & 43.860 & 5.862 & 160.668 & 68.049 & 18.244 & - & 5.725 & 14.769 & 317.177 \\
\hline 2 & Jalan & 703 & - & 866 & - & - & 900 & 88 & - & 2.557 \\
\hline 3 & Sarana Komersial & - & 1.244 & - & - & 13.309 & 1.560 & 3.243 & 24.666 & 44.022 \\
\hline 4 & $\begin{array}{l}\text { Sarana } \\
\text { Industri/Pergudangan }\end{array}$ & 40.949 & - & - & - & - & - & - & 1.043 & 41.992 \\
\hline 5 & Sarana Ibadah & - & 126 & 302 & - & 738 & - & - & - & 1.166 \\
\hline 6 & Sawah & 12.961 & 10.005 & - & - & - & - & - & - & 22.966 \\
\hline 7 & Kebun & - & - & - & - & 1.795 & - & - & - & 1.795 \\
\hline 8 & Rawa & 71.283 & - & - & - & - & - & - & - & 71.283 \\
\hline 9 & $\begin{array}{l}\text { Ruang Terbuka/Tanah } \\
\text { Kosong }\end{array}$ & - & - & 6.840 & 3.744 & - & 6.255 & - & 135 & 16.974 \\
\hline 10 & Tubuh Air/Waduk/Danau & 38.548 & 4.034 & 31.419 & 31.939 & 13.955 & 5.193 & 5.345 & 18.904 & 149.337 \\
\hline
\end{tabular}

Kecamatan Kertapati yang sebagian besar sempadan sungainya tererosi, disisi lain masih memiliki lahan yang tersedimentasi seluas $21.271 \mathrm{~m}^{2}(3,18 \%)$. Sempadan yang tersedimentasi tepatnya berada di wilayah sebelum pertemuan dengan Sungai Kramasan dan Sungai Ogan. Lahan sedimen di sepanjang sempadan Kecamatan Kertapati dimanfaatkan sebagai lahan sawah (44\%) dan waduk (3\%). Hal ini dipengaruhi juga oleh lambatnya perkembangan sektor ekonomi dan perdagangan di wilayah ini dibandingkan di wilayah kota, sehingga sempadan sungai lebih dominan dimanfaatkan untuk lahan pertanian. Pemerintah kolonial belanda telah berupaya meningkatkan infrastruktur di Kecamatan Kertapati sebagai daerah penyangga Kota Palembang yaitu dengan membangun Jembatan Ogan "wilhelmina brug" yang melintasi Sungai Ogan (Santun, 2011).

Pemanfaatan lahan sempadan untuk sarana komersial dan perdagangan paling besar terdapat di Kecamatan Ilir Timur 2. Diantaranya adalah Pelabuhan Boom Baru di Kelurahan 3 Ilir sebagai pelabuhan bongkar muat industri, pusat industri dan bengkel-bengkel yang terletak di Kelurahan 10 Ilir dan 11 Ilir yang berfungsi untuk menunjang sektor sosial ekonomi di Pasar Kuto dan sektor industri dari Pelabuhan Boom Baru. 

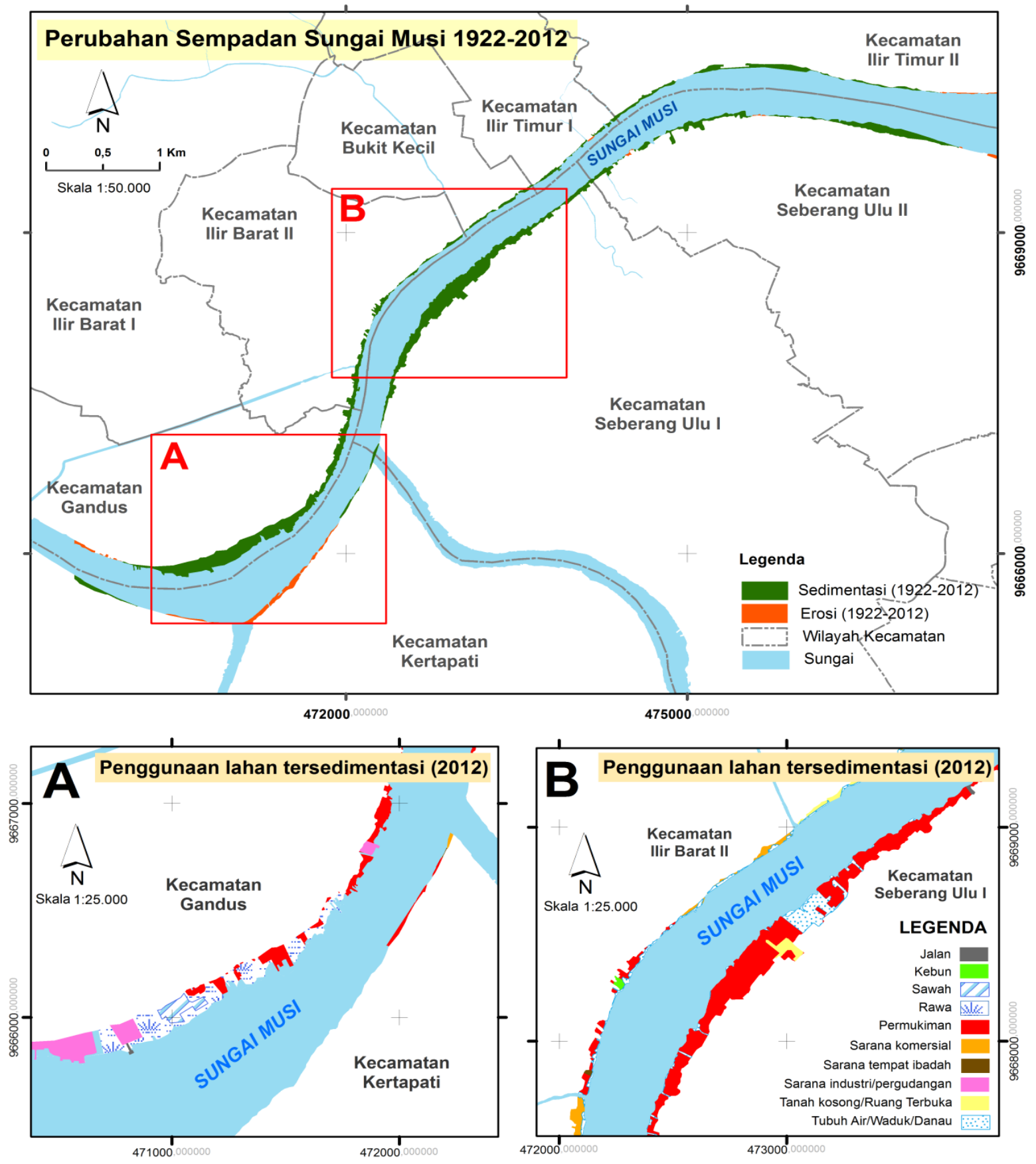

Gambar 6. Lahan hasil sedimentasi dan erosi dari Tahun 1922 hingga 2012.

(A) Penggunaan lahan yang tersedimentasi Tahun 2012 di Kecamatan Gandus;

(B) Penggunaan lahan yang tersedimentasi Tahun 2012 di Kecamatan

Seberang Ulu I dan Kecamatan Ilir Barat II

\section{KESIMPULAN}

Sungai senantiasa mengalami dinamika secara spasial dan temporal.

Dinamika spasial dan temporal dari sungai yang mudah diamati adalah morfologi, pola aliran, dan penggunaan lahan pada kurun waktu yang berbeda. 
Pemanfaatan peta historis dalam kurun waktu tertentu dengan mengaplikasikan Sistem Informasi Geografis (SIG) sebagai alat untuk menganalisis perubahan sempadan sungai telah dapat menghasilkan keluaran (output) secara cepat, mudah, dan akurat. Hasil analisis perubahan sempadan sungai di Kota Palembang dalam kurun waktu 90 tahun terakhir menunjukkan bahwa sedimentasi di Sungai Musi memegang peran dominan dibandingkan proses erosi. Lahan yang tersedimentasi saat ini khususnya di pusat kota dengan banyaknya campur tangan dari manusia telah banyak dimanfaatkan sebagai lahan permukiman, sarana komersial, industri dan pergudangan.

Perubahan Sungai Musi di Kota Palembang merupakan rancangan produk pembelajaran dengan mengangkat tema daerah asal sebagai fokus utama, karena secara keseharian beberapa wilayah ini telah banyak dikenal oleh peserta didik. Harapan dari rancangan produk pembelajaran yang berbasis SIG ini adalah dapat meningkatkan kemampuan berpikir spasial peserta didik terhadap kondisi sekitar. Sasaran peserta didik dalam penelitian ini adalah siswa tingkat sekolah menengah atas dan mahasiswa untuk perkuliahan Sistem Informasi Geografis, Geologi, Geomorfologi, dan Hidrologi.

\section{DAFTAR PUSTAKA}

Asdak. C., 1995. Hidrologi dan Pengelolaan Daerah Aliran Sungai. Yogyakarta: Gadjah Mada University Press.

Badan Pusat Statistik Kota Palembang. 2015. Palembang dalam Angka Tahun 2015 (Palembang in Figure 2015).

Badri, I., 1983. Penyelidikan Geologi Lingkungan Perkotaan Palembang dan Sekitarnya, Sumatera Selatan. Direktorat Geologi Lingkungan. Tidak dipublikasikan.

Bagli S., and Soille P., 2003. Morphological Automatic Extraction of Pan-European Coastline from Ldansat ETM+images. International symposium on GIS dan Computer Cartography for Coastal Management. October. Genova.

BP DAS Musi dan Forum DAS Sumatera Selatan. 2011. Penyusunan Rencana Pengelolaan DAS Terpadu DAS Musi.

Brookes, A. 1994. River Channel Change. In: Calow, P., Petts, G.E. (ed) The River Handbookz: Hydrological and Ecological Principles. pp 55-75. Blackwell Sciences Ltd.

Buffington, J.M. 2012. Changes in channel morphology over human time scales. In: Church, M., Biron, PM., Roy AG., (eds). Gravel-bed Rivers: Processes, Tools, Environments. pp 435-463. John Wiley \& Sons, Ltd.

Chang, Kang-Tsung., 2012. Introduction to Geographic Information Systems, Sixth Edition. New York: The McGraw-Hill Companies, Inc.

Goodchild, M.F., 2009. What problem? Spatial Autocorrelation and Geographic Information Science. Geographical analysis 41: 411-417

Gregory, K.J., 1977. The context of river channel changes. In: Gregory, KJ. (ed) River Channel Changes, pp 1-12. John Wiley \& Sons, Chichester.

Gurnell, A.M. 1997. Channel change on The River Dee Meanders, 1946-1992, from the analysis of air photographs. Regulated Rivers: Research \& Management, Vol. 13: 13-26. 
Gurnell, A.M., Downward, S.R., and Jones, R., 1994. Channel planform change on the River Dee Meanders, 1976-1992. Regulation River. Vol 9: 187-204.

Ishikawa, T., 2015. Spatial Thinking in Geographic Information Science: Students' Geospatial Conceptions, Map-Based Reasoning, and Spatial Visualization Ability. Annals of the Association of American Geographers. DOI: 10.1080/00045608.2015.1064342.

Junaidi, Fatona Fadjii. 2014. Analisis Distribusi Kecepatan Aliran Sungai Musi (ruas jembatan ampera sampai dengan pulau kemaro). Jurnal Teknik Sipil dan Lingkungan. Vol.2 No.3 September 2013, ISSN. 2355-374x.

Kastens, K. A., and T. Ishikawa. 2006. Spatial thinking in the geosciences and cognitive sciences: A cross-disciplinary look at the intersections of the two fields. In Earth and mind (Special Paper 413), ed. C. A. Manduca and D. W. Mogk, 53-76. Boulder, CO: Geological Society of America.

Kennedy, M., 2013. Introducing Geographic Information Systems with ArcGIS: A Workbook Approach to Learning GIS, Third Edition. New Jersey: John Wiley \& Sons, Inc.

Li, Luqian., Lu, Xixi., Chen, Z., 2007. River channel changes during the last 50 years in the middle Yangtze River, The Jianli Reach. Geomorphology 85: 185-196.

Mills JP, Buckley SJ, Mitchell HL, Clarke PJ, Edwards SJ. 2005. A Geomatic Data Integration Technique for Coastal Change Monitoring. Earth Surface Processes dan Landform 30. Pp 651-664.

Moechtar, H., 2007. Evolusi Pengendapan Sedimen Kuarter di Daerah Utara Air Musi, Kota Palembang, Sumatera Selatan. Jurnal Geologi Indonesia Vol. 2. No. 1 Maret 2007, Hal: 1-13.

National Research Council. 2006. Learning to think spatially. Washington, DC: National Academies Press.

Noor, Djauhari. 2012. Pengantar Geologi. Fakultas Teknik Universitas Pakuan. Bogor.

Ollero, A. 2010. Channel changes and floodplain management in the meandering middle Ebro River, Spain. Geomorphology 117: 247-260.

Petts, G.E., 1989. Historical analysis of fluvial hydrosystems. In: Petts GE., Moller H., Roux AL. (Eds). Historical Change of Large Alluvial Rivers: Western Europe, pp. 118. John Wiley \& Sons, Chichester.

Petts, G.E., Amoros, C., 1984. Fluvial Hydrosystems. Chapman and Hall. London. pp 322.

Santun, Dedi I.M., 2011. Venesia dari Timur: Memaknai Produksi dan Reproduksi Simbolik Kota Palembang dari Kolonial sampai Pasca Kolonial. Yogyakarta: Penerbit Ombak

Sarma, J.N., Borah, D., and Goswami, U., 2007. Change of river channel and bank erosion of The Burhi Dihing River (Assam), Assessed using remote sensing data and GIS. Journal of The Indian Society of Remote Sensing. Vol 35, No. 1: 93-100.

Sunarto. 2004. Perubahan Geomorfologi pada Wilayah Kepesisiran di Sekitar Gunungapi Muria. PhD dissertation. Gadjah Mada University, Yogyakarta, Indonesia.

Susanto, Robiyanto H., 2013. Permasalahan di DAS Musi. Bahan Ajar Mata Kuliah Ekosistem Lahan Basah. Program S2 Pengelolaan Lingkungan, Program Pascasarjana, Universitas Sriwijaya. Tidak dipublikasikan.

Tileston, D.W., 2003. What Every Teacher Should Know About Media and Technology. Corwin Press.

Trimble, S.W., and Cooke, R.U., 1991. Historical Sources for Geomorphological Research in The United States. The Professional Geographer Vol 43, Issue 2, May 1991. pp: 212-228

Utomo, M., et al., 1992. Pembangunan dan Pengendalian Alih Fungsi Lahan. Universitas Lampung. Bandar Lampung.

Peraturan Pemerintah Republik Indonesia Nomor 38 Tahun 2011 Tentang Sungai 